\begin{tabular}{c} 
Volume and Issues Obtainable at Center for Sustainability Research and Consultancy \\
Journal of Business and Social Review in Emerging Economies \\
ISSN: $2519-089 X(E): 2519-0326$ \\
Volume 6: Issue 2 June 2020 \\
ᄃSR \\
Journal homepage: $\underline{\text { www.publishing.globalcsrc.org/ibsee }}$ \\
\hline
\end{tabular}

\title{
Exploring Gender Differences in Attitude towards Mathematics at Secondary Level in Pakistan
}

\author{
${ }^{1}$ Tahira Batool, ${ }^{2}$ Sofia Akhter, ${ }^{3}$ Tahira Kalsoom \\ ${ }^{1}$ Research and Evaluation Department, Lahore College for Women University, Lahore Pakistan, \\ tahirashehbaz@yahoo.com \\ ${ }^{2}$ Government School Education Department, Depalpur Pakistan \\ ${ }^{3}$ Research and Evaluation Department, Lahore College for Women University, Lahore Pakistan.
}

\begin{tabular}{l}
\hline ARTICLE DETAILS \\
\hline History \\
Revised format: May 2019 \\
Available Online: June 2020
\end{tabular}

\section{Keywords}

Attitude, gender difference, mathematics, secondary

level

JEL Classification

M1, M12

\begin{abstract}
This study was aimed to find out the attitude towards mathematics which were communicating gender difference among secondary level students. A quantitative research approach was used to explore gender difference in relation to the attitude towards mathematics among nine graders. Fifty seven public sector schools in Lahore were selected for this research. All nine graders in public sector secondary schools were target population of current study. Eleven hundred and eighty six students were selected through multistage random sampling for present research. A questionnaire developed by the researcher was used for exploration of gender difference in relation to students' attitude towards mathematics at secondary level in Pakistan. It was a Lekert Scale with five points on it. The questionnaire was pilot tested and validated by experts. It was found that overall gender difference in attitude towards mathematics did not significantly exists. Therefore, the reason of difficulty in mathematics is needed to be explored for both boys and girls.
\end{abstract}

\section{OPEN ACCESS}

(C) 2020 The authors, under a Creative Commons Attribution-

NonCommercial 4.0

Corresponding author's email address: tahirashehbaz@yahoo.com

Recommended citation: Batool, T., Akhter, S., and Kalsoom, T. (2020). Exploring Gender differences in attitude towards Mathematics at Secondary Level in Pakistan. Journal of Business and Social Review in Emerging Economies, 6(2), 587-596

\section{Introduction}

Attitude has a vital role in students' achievement in mathematical studies. Researches has shown positive attitude leaded towards success in mathematics. Effort to progress mathematics at lower secondary level offers base on upper secondary level mathematical achievements (Ma and Xu, 2004), Educational researchers have reported a considerable gender differences in students' attitude towards mathematics (Amalu, 2016; Boran, Aslaner \& Cakan, 2013; Lee \& Anderson, 2015; Yenilmez, \& Ozabaci, 2003). But the perception about gender difference in attitude towards mathematics is going to be changed (Yasar, 2016). Mathematical studies has believed a central part in school education (Alenezi; 
2008). So mathematics is an important subject for both boys and girls. A research on attitude of high school students in Mathematics has reported a positive trend in students' attitude in the direction of mathematics (Batool, 2019). According to Yenilmez (2007) when students have negative attitude to mathematics they avoid mathematics and feel anxiety. Cockcroft (1982) reported some reasons why people should learn mathematics. He said it is useful for everyday life and provides a means to communicate, explain and predict. He further said that mathematics develops esthetic sense and logical thinking as well. Therefore, serious investigation is required to explore variables affecting mathematics performance in girls or boys at secondary level.

As suggested by Meece and Courtney (1992) that more research is needed to understand how variations on gender-role expectations and socialization experiences influence motivation and achievement patterns in students of different cultures. Therefore, this study was designed to explore difference in students' attitude towards mathematics due to their gender at secondary level in Pakistan.

\section{Literature Review}

At primary school level girls are time and again disappointed from their mathematical activities. Therefore, girls are not comfortable with mathematics at high school years and at university level girls often drop this subject. As a result, ladies are not employed at that job where mathematical expertise are required (Arnot, David \& Weiner, 1996). Wasiche (2006) describes attitude as a feeling towards anything that is reflected in a peoples' behavior. Attitudes mostly depends on someone's personal experience in the learning environment. According to Orton (1987) mathematical abilities are not natural but these are acquired by a person. He further told some have natural characteristics and can develop mathematical abilities, though, he is not completely denying the genetic factor. It has already been recognized that many learners think mathematics as a boring subject for them (Brown, Brown, \& Bibby, 2008). Moreover, Martin (2003) and Watt (2007) claims that there appears to be differences regarding gender in relation to attitudes towards mathematics and future aims. Mata, Monteiro, and Peixoto (2012) has inspected the outcome of individual and social support factors on attitudes towards mathematics in their research and found that, in overall, students thought positive attitudes towards mathematics. They also emphasized on grade and math achievement has effects on attitudes towards mathematics. Gender has no effect on these attitudes. Though, the girls showed a continuous weakening in attitudes as they proceeded in school. Ifamuyiwa and Akinsola (2008) has also examined moderating effects of locus of control and gender on senior secondary level students' attitude towards mathematics and found no significant main effects of gender on the participants' attitude towards mathematics. According to Farooq and Shah (2008) students' attitudes also influence the rate of response during the class lessons. They further told that positive attitude affect achievement positively.

They examined five factors in their research on a sample of 685 Pakistani students. These factors are confidence about mathematics, its usefulness as a subject, mathematics as a male domain and teachers' perception about students. They find out no notable difference regarding students' gender in this research. Furthermore, the analysis of overall data collected in this survey on attitude of secondary level students in Pakistan has exposed no difference in attitude due to students' gender. towards mathematics. They have concluded that male and female students in Pakistan have almost similar attitude towards mathematics. Therefore, the extent of students pass fail depends upon their attitudes in this subject. It was expressed that students' attitude towards mathematics may reflect teachers' attitudes for teaching mathematics. When the mathematics teacher feels that the subject consists of rote learning devoid of understanding, he/she would transmit these feelings to the students. In this way, students' feel that mathematics is a tough subject. As a result of this, the students don't effort to develop interest in it (e.g. Popoola \& Olarewaju; 2010). There are different reasons of differences in attitudes due to gender. It is possible that any truly inclusive clarification might need to explain this complex mixture of factors. But, gender stereotyping is often mentioned as a possible reason of these differences, as it also shore up many other contextual factors like teacher, peer attitudes and parents approach that can effect boys and girls attitudes and class participation (Mael, 1998). 
Ainley and Fordham (1991) have written for the beauty of school. They examined the pupil and teacher relationship. Based on the studies on attitudes towards mathematics, they established that pupil's gratification in school and their academic success are not connected with each other. Teachers of mathematics are also conscious about pupils' attitude connection with student's mathematical performance. Teaching and learning process of mathematics is closely related to the positive attitude towards mathematics. Another ingredient for mathematical education is confidence on this subject. Students having positive attitude towards mathematics usually enjoy mathematical works but it does not mean that they are positively confident in all the area of Mathematics (Robson, 1996). Nüket Elçi (2017) has investigated attitudes and its impact on teaching approach in mathematics. His research has shown gender related differences in individuals' attitude. He also discussed the wrong way of assessment in mathematics also confuse students which leads to the negative attitudes. Students feel that confusing formulations were at the heart of mathematics. Therefore, their attitudes are not improved in Mathematics.

Likewise, in particular differences in attitudes towards learning due to gender are recent trend in the literature in educational studies (Mata, Monteiro, \& Piexoto; 2012). It is well thought out that boys' achievement and attitudes towards mathematics is better than girls. But conflicting to this concept, some investigators has shown that achievement do not differ considerably among girls andboys in mathematics (e.g., Lindberg, Hyde, Petersen, \& Linn, 2010; Scafidi \& Bui, 2010). The similarities in performance of boys and girls is also reported by Lindberg, Hyde, Petersen, \& Linn, (2010) in a metaanalysis of data collected from 12860350 students in 242 different studies. They found that there were no noteworthy gender differences in both male and female learners' performance. Kaur (2017) has examined five dimensions of attitude towards mathematics in her study. She also explored gender difference in self-confidence, usefulness and motivation in her research, she found no difference regarding students' gender in this research. Kaur found that male and female nine graders in sample of this research has similar attitude towards mathematics.

Many students discover their ability in mathematics as boring and frustrating activity (Brown, Brown, \& Bibby, 2008), and for mathematics Watt (2004) has also shown in his study decline of attitude as they grow up in school. Researchers should play a role in developing new understandings and investigating ways to recover the learning of mathematics. Avoidance is a rising issue in teaching and learning of mathematics (Ashcraft \& Moore, 2009). Students love mathematics but after failure in this subject their point of view changed. Therefore, failure in mathematics leads towards negative attitude. Attitude of pupils' contribute a lot in development of pupils awareness about mathematical learning. It improves the adaptability and applicability in the students (Batool, 2019; Schiefele \& Csikszentmihalyi, 1995).Parents can also play a role in student attititude during curricular and co-curricular activities (e.g. Batool \& Raiz, 2019; Batool \& Raiz, 2020). Present study was focused to see attitude towards mathematics in relation to gender differences among students at secondary level in Pakistan.

\section{Research Questions}

Main question of the study is;

Q What is gender difference in students' attitude towards mathematics?

a. Is gender difference exist in students' liking of mathematics?

b. Is there any difference exists due to gender in students' confidence to Mathematics?

c. Is there any difference regarding students' views about Mathematics as a subject exist due to gender?

d. Are students' views about Mathematics class different due to their gender?

e. Are students' views about Mathematics examination different due to their gender?

f. Are students' views about sources of seeking help different due to their gender? 
g. Are students' overall attitude towards Mathematic different due to their gender?

\section{Methodology}

\subsection{Population and Sample}

Students of all public sector secondary schools of boys and girls in Lahore were population of this study. By random sampling 57 Government high schools were selected, from which 1186 grade nine students (62\% boys and $38 \%$ girls) participated in this study. Only grade nine students (mean age $=15$ years) in selected schools were target population of current study.

\subsection{Research Instrument}

In order to explore difference due to gender in nine graders' attitude towards mathematics, a questionnaire was developed on the basis of these points, students' liking of mathematics, confidence towards mathematics, and students' views about mathematics as a subject and mathematics classes and examination, students' sources of seeking help in mathematics. Before final use, instrument was pilot tested and reliability coefficient for final draft were found to be .69 for students' liking of mathematics, .58 for confidence towards mathematics, .78 for students' views about mathematics as a subject and .79 for mathematics class and .71 for examination, .56 for students' sources of seeking help in mathematics. Reliability coefficient for overall questionnaire was found 0.89. It was basically a Lekert Scale with five points on it. The questionnaire was consisted on thirty eight items. Cronbach alpha for the scale was encouraging which is considered very suitable (Linn \& Gronuld, 2000). Questionnaire was validated by a panel of experts.

\subsection{Research Design}

The study was exploratory research in nature. Quantitative research approach was used to examine the differences among groups (both male and female). The survey method was followed to examine the gender differences in attitude of secondary level students towards mathematics.

\section{Results}

Data collected were on a scale from 1186 participants. After that data were analyzed by using SPSS Version 16. Following results were obtained by comparing the means of groups with help of independent samples t-test. It was appropriate measures to find difference among groups.

Table 1

\section{A Comparison of Boys and Girls (students) Liking of mathematics}

\begin{tabular}{lllllll}
\hline \multicolumn{1}{c}{ Statements } & Gender & Yes & No & $\begin{array}{l}\text { Value } \\
\boldsymbol{\chi}^{\mathbf{2}}\end{array}$ & Df & Sig \\
\hline I like mathematics because I am good in it & Male & 379 & 341 & 5.47 & 5 & .263 \\
& Female & 239 & 211 & & & .957 \\
I like mathematics because I know its logics & Male & 323 & 221 & .377 & 3 & .957 \\
& Female & 198 & 219 & & & \\
I like mathematics because I have a good mathematics & Male & 309 & 401 & .346 & 2 & .849 \\
teacher & Female & 198 & 247 & & & \\
I have constantly liked mathematics & Male & 266 & 405 & 2.68 & 2 & .351 \\
& Female & 139 & 295 & & & \\
I like it because mathematics is helpful in my life & Male & 201 & 531 & 3.733 & 2 & .194 \\
& Female & 100 & 345 & & & \\
Mathematics can help me in my job in future & Male & 288 & 440 & .101 & 2 & .951 \\
& Female & 179 & 263 & & & \\
I often get good grades in this subject & Male & 315 & 417 & .162 & 2 & .922 \\
& Female & 189 & 256 & & & \\
\hline
\end{tabular}

Table above indicates that there was no noteworthy difference in boys and girls (students) liking toward 
mathematics. Both male and female students have similar attitude regarding liking towards mathematics. They feel mathematics will not help in career and future. They could not get good marks, both boys and girls were agreed on.

Table 2

A Comparison of Boys and Girls (Students) Confidence towards Mathematics

\begin{tabular}{|c|c|c|c|c|c|c|c|c|c|}
\hline Give your opinion & Gender & $\begin{array}{l}\mathrm{St} \\
\mathrm{Ag}\end{array}$ & $\mathrm{Ag}$ & $\mathrm{N}$ & $\begin{array}{l}\mathrm{D} \\
\mathrm{Ag}\end{array}$ & $\begin{array}{l}\mathrm{St} \\
\mathrm{DAg}\end{array}$ & $\begin{array}{l}\text { Value } \\
\chi^{2}\end{array}$ & Df & Sig \\
\hline I am confident in mathematics & Male & 319 & 145 & 121 & 57 & 87 & 2.481 & 6 & .871 \\
\hline Mathematics is too abstract for me & $\begin{array}{l}\text { Female } \\
\text { Male }\end{array}$ & $\begin{array}{l}205 \\
157\end{array}$ & $\begin{array}{l}91 \\
87\end{array}$ & $\begin{array}{l}67 \\
145\end{array}$ & $\begin{array}{l}26 \\
189\end{array}$ & $\begin{array}{l}52 \\
144\end{array}$ & 6.56 & 6 & .364 \\
\hline & Female & 110 & 68 & 76 & 100 & 85 & & & \\
\hline I am getting worse in mathematics & $\begin{array}{l}\text { Male } \\
\text { Female }\end{array}$ & $\begin{array}{l}138 \\
117\end{array}$ & $\begin{array}{l}106 \\
76\end{array}$ & $\begin{array}{l}170 \\
92\end{array}$ & $\begin{array}{l}162 \\
79\end{array}$ & $\begin{array}{l}144 \\
72\end{array}$ & 15.57 & 6 & .024 \\
\hline I feel I am copping well & $\begin{array}{l}\text { Male } \\
\text { Female }\end{array}$ & $\begin{array}{l}176 \\
119\end{array}$ & $\begin{array}{l}129 \\
61\end{array}$ & $\begin{array}{l}147 \\
82\end{array}$ & $\begin{array}{l}147 \\
88\end{array}$ & $\begin{array}{l}128 \\
89\end{array}$ & 6.203 & 6 & .287 \\
\hline Mathematics classes are boring & $\begin{array}{l}\text { Male } \\
\text { Female }\end{array}$ & $\begin{array}{l}313 \\
201\end{array}$ & $\begin{array}{l}115 \\
71\end{array}$ & $\begin{array}{l}117 \\
59\end{array}$ & $\begin{array}{l}61 \\
47\end{array}$ & $\begin{array}{l}123 \\
62\end{array}$ & 4.911 & 6 & .427 \\
\hline
\end{tabular}

Table above indicates that no noteworthy difference in girls and boys (students) confidence towards mathematics. Only the statement in which it is asked that they are getting worse in mathematics has a significant gender difference. So, there is no gender difference regarding students' confidence towards mathematics.

\section{Table 3}

A comparison of girls and boys (Students) Views on Mathematics as a subject

\begin{tabular}{|c|c|c|c|c|c|c|c|c|c|}
\hline Statements & Gender & $\begin{array}{l}\mathrm{St} \\
\mathrm{Ag}\end{array}$ & $\mathrm{Ag}$ & $\mathrm{N}$ & $\begin{array}{l}\mathrm{D} \\
\mathrm{Ag}\end{array}$ & $\begin{array}{l}\mathrm{St} \\
\mathrm{DAg}\end{array}$ & $\begin{array}{l}\text { Value } \\
\chi^{2}\end{array}$ & Df & Sig \\
\hline Mathematics is an abstract subject & Male & 392 & 147 & 17 & 67 & 81 & 13.447 & 6 & .017 \\
\hline & Female & 177 & 82 & 27 & 68 & 61 & & & \\
\hline Mathematics is a difficult subject & Male & 129 & 106 & 120 & 139 & 211 & 6.26 & 8 & .619 \\
\hline & Female & 76 & 80 & 77 & 75 & 124 & & & \\
\hline Mathematics is unrelated to life & $\begin{array}{l}\text { Male } \\
\text { Female }\end{array}$ & $\begin{array}{l}99 \\
59\end{array}$ & $\begin{array}{l}106 \\
64\end{array}$ & $\begin{array}{l}190 \\
100\end{array}$ & $\begin{array}{l}97 \\
56\end{array}$ & $\begin{array}{l}229 \\
156\end{array}$ & 4.68 & 6 & .580 \\
\hline Mathematics is a boring subject & $\begin{array}{l}\text { Male } \\
\text { Female }\end{array}$ & $\begin{array}{l}72 \\
39\end{array}$ & $\begin{array}{l}96 \\
57\end{array}$ & $\begin{array}{l}171 \\
98\end{array}$ & $\begin{array}{l}130 \\
77\end{array}$ & $\begin{array}{l}231 \\
152\end{array}$ & 1.453 & 5 & .920 \\
\hline Mathematics is not useful for career & $\begin{array}{l}\text { Male } \\
\text { Female }\end{array}$ & $\begin{array}{l}128 \\
63\end{array}$ & $\begin{array}{l}139 \\
89\end{array}$ & $\begin{array}{l}107 \\
63\end{array}$ & $\begin{array}{l}101 \\
71\end{array}$ & $\begin{array}{l}253 \\
154\end{array}$ & 2.268 & 5 & .512 \\
\hline Mathematics is a complicated subject & $\begin{array}{l}\text { Male } \\
\text { Female }\end{array}$ & $\begin{array}{l}302 \\
141\end{array}$ & $\begin{array}{l}125 \\
55\end{array}$ & $\begin{array}{l}98 \\
60\end{array}$ & $\begin{array}{l}82 \\
71\end{array}$ & $\begin{array}{l}106 \\
102\end{array}$ & 12.728 & 5 & .026 \\
\hline
\end{tabular}

Table above point out that there is no noteworthy difference in girls and boys' (students) attitude towards mathematics as a subject. So, there was overall no difference due to their gender regarding students' views about mathematics as a subject. Both girls and boys (students) feel mathematics is a boring and difficult subject.

Table 4

A comparison of Girls and Boys (Students) View about Mathematics classes

\begin{tabular}{|c|c|c|c|c|c|c|c|c|c|}
\hline Statements & Gender & $\mathrm{Al}$ & Oft & ST & Rar & $\mathrm{NeV}$ & $\begin{array}{l}\text { Value } \\
\chi^{2}\end{array}$ & $\mathrm{df}$ & Sig \\
\hline \multirow[t]{2}{*}{ I do not understand what is taught } & Male & 227 & 111 & 218 & 45 & 125 & 7.619 & 5 & .179 \\
\hline & Female & 121 & 56 & 134 & 28 & 101 & & & \\
\hline \multirow{2}{*}{ I find doing mathematics problems repetitive } & Male & 136 & 192 & 250 & 71 & 72 & 6.502 & 5 & .260 \\
\hline & Female & 73 & 115 & 150 & 49 & 42 & & & \\
\hline \multirow[t]{2}{*}{ The explanations are not clear } & Male & 136 & 194 & 250 & 71 & 72 & 6.567 & 5 & .260 \\
\hline & Female & 73 & 115 & 150 & 49 & 44 & & & \\
\hline
\end{tabular}


It is difficult to be sure what is right to do

I find I make many mistakes

There is too much homework

\begin{tabular}{lllllllll} 
Male & 95 & 146 & 285 & 104 & 71 & 12.45 & 5 & .029 \\
Female & 42 & 89 & 153 & 52 & 91 & & & \\
Male & 110 & 242 & 201 & 53 & 107 & 13.86 & 5 & .018 \\
Female & 42 & 101 & 111 & 117 & 96 & & & \\
Male & 122 & 138 & 260 & 72 & 127 & 1.328 & 5 & .923 \\
Female & 71 & 77 & 156 & 49 & 85 & & & \\
\hline
\end{tabular}

This table indicates that there is no noteworthy difference in (girls and boys) students' attitude towards mathematics classes. Only the statements in which it is asked that they are they are not sure what should do and they find they make many mistakes have significant gender difference. So, gender difference regarding students' attitude towards mathematics classes is not notable. Moreover, both girls and boys (students) cannot understand what is taught and feel difficulties in understanding explanations given in the classrooms. They also feel that homework is too much.

Table 5

A comparison of Students' View about Mathematics Examination

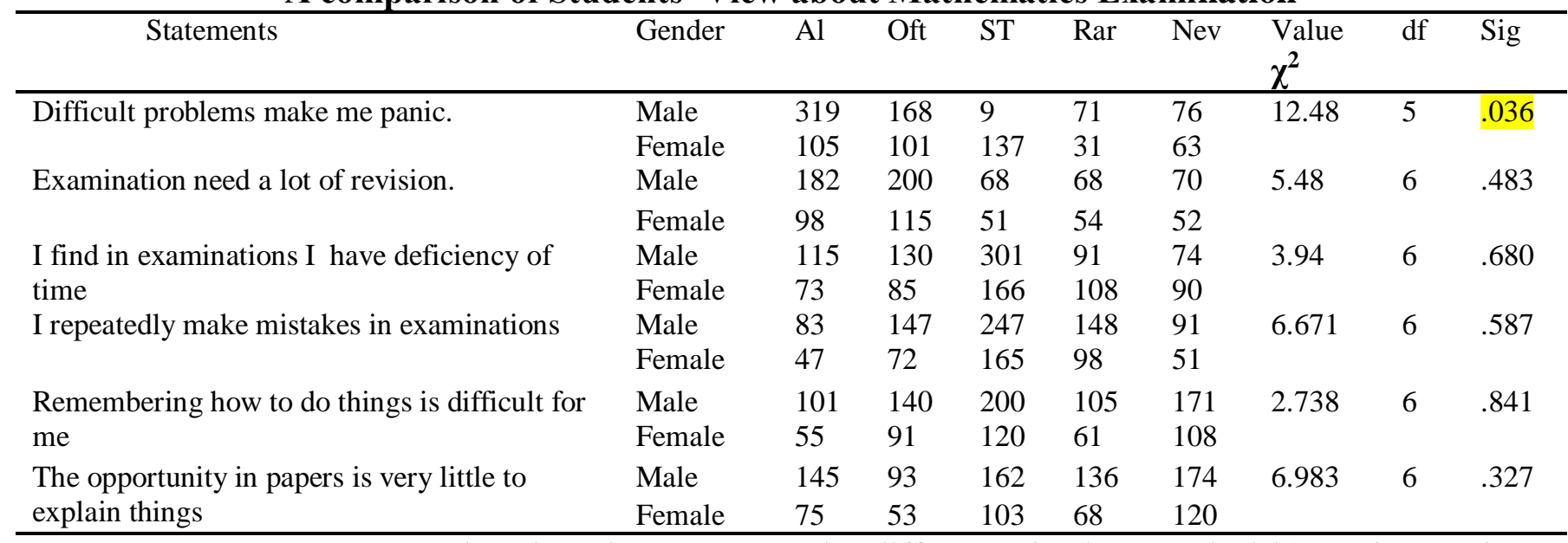

From this table we can see that there is no noteworthy difference in (boys and girls) students' views about mathematics examinations. Only the statements in which it is asked that I tend to panic with difficult problems have significant gender difference $(0.036<0.05)$. So, overall gender difference regarding students' views about mathematics examination is not significant. Both male and female students have shortage of time and make mistakes in mathematics examinations. Both have a little opportunity to explain things mathematics examinations.

Table 6

Comparison Girls and Boys (Students) Views about Sources of Seeking Help in Mathematics

\begin{tabular}{|c|c|c|c|c|c|c|}
\hline Statements & Gender & Yes & No & $\begin{array}{l}\text { Value } \\
\chi^{2}\end{array}$ & Df & Sig \\
\hline \multirow{2}{*}{$\begin{array}{l}\text { I Practice mathematics problems till get the right } \\
\text { solution. }\end{array}$} & Male & 399 & 321 & \multirow[t]{2}{*}{6.47} & \multirow[t]{2}{*}{5} & \multirow[t]{2}{*}{.263} \\
\hline & Female & 219 & 221 & & & \\
\hline \multirow[t]{2}{*}{ Carefully reading text books helps me a lot } & Male & 313 & 217 & \multirow[t]{2}{*}{.317} & \multirow[t]{2}{*}{3} & \multirow[t]{2}{*}{.957} \\
\hline & Female & 185 & 259 & & & \\
\hline \multirow{2}{*}{$\begin{array}{l}\text { Working with my friends is useful to understand the } \\
\text { mathematical ideas. }\end{array}$} & Male & 319 & 413 & \multirow[t]{2}{*}{.326} & \multirow[t]{2}{*}{2} & \multirow[t]{2}{*}{.849} \\
\hline & Female & 188 & 257 & & & \\
\hline \multirow[t]{2}{*}{ My source of help is my parents in this subject } & Male & 415 & 276 & \multirow[t]{2}{*}{2.40} & \multirow[t]{2}{*}{2} & \multirow[t]{2}{*}{.361} \\
\hline & Female & 295 & 150 & & & \\
\hline \multirow[t]{2}{*}{ Pictures or diagrams helps me a lot } & Male & 201 & 531 & \multirow[t]{2}{*}{3.743} & \multirow[t]{2}{*}{2} & \multirow[t]{2}{*}{.154} \\
\hline & Female & 100 & 345 & & & \\
\hline \multirow[t]{2}{*}{ Learning the methods taught in class by my teacher } & Male & 440 & 288 & \multirow[t]{2}{*}{.101} & \multirow[t]{2}{*}{2} & \multirow[t]{2}{*}{.951} \\
\hline & Female & 263 & 187 & & & \\
\hline \multirow{2}{*}{ I have agreed in my mind what I have to do } & Male & 315 & 417 & \multirow[t]{2}{*}{.162} & \multirow[t]{2}{*}{2} & \multirow[t]{2}{*}{.922} \\
\hline & Female & 189 & 256 & & & \\
\hline I always try to get the right answer. & Male & 283 & 449 & 2.449 & 2 & .178 \\
\hline
\end{tabular}


Female

196

249

Table above point out that there is no noteworthy change in male and female students' sources of seeking help in mathematics studies. So, gender difference regarding students' sources of seeking help in mathematics studies is not significant. Both male and female students were agreed that practicing many mathematics exercise, reading text books carefully, working with friends and seeking help from parents is helpful. Similarly, boys and girls respond on the statements that learning the methods taught in class by my teacher and making sure to try to get the right answer.

\section{Discussions}

The study exposed that there is no noteworthy change in students' liking about mathematics in both girls and boys. Male and female students also has equal level of liking mathematics. There was same level of confidence towards mathematics for both groups of students. These results has accordance with study of Farooq \& Shah (2008) and Kaur (2017. They have shown no gender difference in students' confidence in mathematics. The gender difference was not notable in case of students' views about mathematics classes and students' views about mathematics as subject. Both gender of students have same kind of opinion about mathematics at secondary level that is in line with the study of Lee and Anderson (2015). Acording to Amalu (2016) there was a major difference in boys and female students' thinking about mathematics as a complicated subject these results are in contrast with the current study.

The answer to the research question that "is difference in views about mathematics examinations exists in boys and girls at secondary level" is "no" in current study. Students' views about mathematics examinations in case of both boys and female students are almost the same (e.g.Schiefele \& Csikszentmihalyi, 1995; Alenezi, 2008). Findings of current study has also shown that there is no major difference in students' sources of seeking help in both boys and girls. Both male and female students need same type of help. Both male and female student were seeking help by practicing many mathematics exercise and problem until they get them right answer and by reading their text books carefully. Seeking help is a form of feedback given by the helper (e.g. parents), so, they think feedback is helpful in achieving good grades for students (Batool \& Akhter, 2018; Batool \& Akhter, 2019). They were agree that following the methods taught by the teacher carefully was very helpful for them. In the same way, seeking help from their parents was found useful in their mathematical studies in both male and female students.

The findings of the study revealed that there is no noteworthy variation in students' attitude towards mathematics due to their gender. This is in line with the research finding of some previous researches (Alenezi, 2008; Farooq \& Shah, 2008; Yasar, 2016; Kaur, 2017). At the last of this discussion we can say that there is a need of considering issues related to mathematics for both male and female students.

\section{Conclusion and Recommendations}

In the light of the findings of the current study gender difference in attitude towards mathematics is declining in grade nine students in Pakistan. But still there is need to explore gender differences regarding mathematics classes. Avoidance was an upward question in mathematics education (Ashcraft \& Moore, 2009). There is need to find out difference regarding ability level of secondary level students attitude and other factors like giving feedback in mathematics (e.g. Batool, 2020b). Students' selfefficacy and self-regulation is also a matter of consideration in students' mathematics achievement (e.g. Batool, 2020a; Batool, Noureen \& Ayuob, 2019; Habiba, Batool, \& Ayesha, 2020). At upper school and university level this type of survey might be conducted to see a clear picture of gender differences regarding the attitude towards mathematics. Both Girls and Boys (Students) feel mathematics as a boring subject so there is a need to introduce new teaching techniques in mathematics learning. Students problems related to their memory or other health issue should also be explored because these variables may also affect attitudes (Batool, Habiba \& Saeed, 2019). 


\section{References}

Ainley, J. and A. Fordham (1991). The development and application of national indicators of educational effectiveness. In: J. Hewton (ed.), Performance Indicators in Education: What can they tell us? Brisbane:Department of Education, Queensland.

Alenezi, D. (2008). A study of learning mathematics related to some cognitive factors and to attitudes (Doctoral dissertation, University of Glasgow).

Amalu, M. N. (2016). Gender differences in attitude towards mathematics in Nigerian secondary schools. Sophia: An African Journal of Philosophy, 17(1), 191-197.

Arnot, M., David, M., \& Weiner, G. (1996). Educational reforms and gender equality. Manchester.

Ashcraft, M. H,. \& Moore, A. M. (2009). Mathematics anxiety and the affective drop in performance. Journal of Psycho educational Assessment, 27(3), 197-205.

Batool, T. \& Akhter, M. (2018). Effect of feedback on students' Engagement and Achievement in Mathematics in Secondary Schools. (Doctoral dissertation, University of the Punjab, Pakistan).

Batool, T., Noureen, G., \& Ayuob, Z. (2019). Relating Learner Empowerment with Learner SelfRegulation Learning in Higher Education. Review of Economics and Development Studies, 5(4), 755-766.

Batool, T. \& Raiz, J., (2020). Exploring Parents Involvement in University Students Education. Journal of Business and Social Review in Emerging Economies, 6(1), 187-196. DOI: 10.26710/jbsee.v6i1.1037.

Batool, T. \& Raiz, J., (2019). Variations in Parental Participation in Curricular and Co-Curricular Activities of University Students. Global Social Sciences Review, 4 (4), 239-249. DOI: 10.31703/gssr.2019 (IV-IV).31.

Batool, T. (2019). Who Love Mathematics? Relating Attitudinal Factors with Mathematics in Public Sector Secondary Schools. Pakistan Journal of Social Sciences,39(4), 1465-1474.

Batool, T. (2020a). Self-efficacy and Self-regulation Linkage with Mathematics Achievement in Girls from Secondary Schools, Journal of Education \& Social Sciences, 8 (1), 92-103. DOI: https://doi.org/10.20547/jess0812008106

Batool, T. (2020b). Feedback Impact in High, Average and Low Achievers' Mathematics Engagement in High Schools' Classrooms. Review of Economics and Development Studies, Vol. 6 (1), 167178.

Batool, T. Habiba, U., \& Saeed, A. (2019). The Relationship between Students' Working Memory Capacity and Mathematical Performance at Secondary School Level. Bulletin of Education and Research, 41(3), 177-192.

Batool, T., \& Akhter, M. (2019). Feedback effect on secondary school students' achievement ion Mathematics. Global Social Sciences Review, 4 (3), 123-134.

Boran, A., Aslaner, R., \& Cakan, C. (2013). Examining the attitudes of first grade pre-service teachers towards mathematics according to some variables. Turkish Journal of Computer and Mathematics Education, 4(1).

Brown, M., Brown, P., \& Bibby, T. (2008). "I would rather die": reasons given by 16 year-olds for not continuing their study of mathematics. Research in Mathematics Education, 10(1), 3-18.

Cockcroft, W. H. (1982). Mathematics counts. London: HM Stationery Office.

Engagement in High Schools' Classrooms. Review of Economics and Development Studies, 6 (1), 167 178.

Farooq, M.S. and Shah, S.Z., (2008).Students' Attitude towards mathematics. Pakistan Economic and Social Review, 46, 75-83. 
Habiba, U., Batool, T., \& Ayesha, S. (2020). Effect of Self-Regulated Learning Strategies on Eighth Grade Students' Motivation for Learning English. Global Social Sciences Review,5 (1), 52-62.

Ifamuyiwa, S. A., \& Akinsola, M. K. (2008). Improving senior secondary school students' attitude towards mathematics through self and cooperative-instructional strategies. International journal of mathematical education in science and technology, 39(5), 569-585.

Kaur, K. (2017). Gender Differences in the Attitude towards Mathematics of Ninth Class Adolescents of Chandigarh. Int. J. Res. Humanit. Soc. Sci., 5(3), 77-81.

Lee, K., \& Anderson, J. (2015). Gender Differences in Mathematics Attitudes in Coeducational and Single Sex Secondary Education. Mathematics Education Research Group of Australasia.

Lindberg, S. M., Hyde, J. S., Petersen, J. L., \& Linn, M. C. (2010). New trends in gender and mathematics performance: a meta-analysis. Psychological bulletin, 136(6), 1123

Linn, R. L., \& Gronlund, N. E. (2000). Measurement and assessment in teaching (8 [th] ed.).

Ma, X., \& Kishor, N. (1997). Assessing the relationship between attitude toward mathematics and achievement in mathematics: A meta-analysis. Journal for research in mathematics education, 26-47.

Mael, F. A. (1998). Single-sex and co-educational schooling: Relationships to socioemotional and academic development. Review of Educational Research, 68(2), 101-129.

Martin, A. J. (2003). Enhancing the educational outcomes of boys: Findings from the ACT investigation into boys' education. Youth Studies Australia, 22(4), 27-36.

Mata, M. D. L., Monteiro, V., \& Peixoto, F. (2012). Attitudes towards mathematics: Effects of individual, motivational, and social support factors. Child development research, 2012.

Mata, M. D. L., Monteiro, V., \& Peixoto, F. (2012). Attitudes towards mathematics: Effects of individual, motivational, and social support factors. Child development research, 2012.

Meece, J. L., \& Courtney, D. P. (1992). Gender differences in students' perceptions: Consequences for achievement-related choices. Student perceptions in the classroom, 209-228.

Meece, J. L., \& Courtney, D. P. (1992). Gender differences in students' perceptions: Consequences for achievement-related choices. Student perceptions in the classroom, 209-228.

Nüket Elçi, A. (2017). Students' Attitudes Towards Mathematics and The Impacts of Mathematics Teachers' Approaches on It. Acta Didactica Napocensia, 10( 2), 99-107.

Orton, A (1987). Learning Mathematics Issues Theory and Classroom Practice. London: Cassel Education Ltd.

Popoola, F. R., \& Olarewaju, R. R. (2010). Factors Responsible for Poor Performance of Students in Mathematics in Nigerian Secondary Schools. Journal of Research in Education and Society, 1(2), 55-65.

Robson, J. (1996). Some outcomes of learning through teleconferencing. Journal of Instructional Science and Technology, 1(3).

Scafidi, T., \& Bui, K. (2010). Gender Similarities in Math Performance from Middle School through High School. Journal of Instructional Psychology, 37(3).

Schiefele, U., \& Csikszentmihalyi, M. (1995). Motivation and ability as factors in mathematics experience and achievement. Journal for research in mathematics education, 163-181.

Wasiche, J. L. (2006). Teaching Techniques That Enhance Students Performance in Mathematics in Selected Public secondary schools in Butere-Mumias District. Kenya. Unpublished M. Ed Thesis. Kenyatta University. 
Watt, H. M. G. (2004). Development of adolescents' self-perceptions, values and task perceptions according to gender and domain in 7th- through 11-th grade Australian students. Child Development, 75, 1556-1574.

Watt, H. M. G. (2007). A trickle from the pipeline: Why girls under participate in maths. Professional Educator, 6(3), 36-41.

Yasar, M. (2016). High School Students' Attitudes towards Mathematics. Eurasia Journal of Mathematics, Science \& Technology Education, 12(4), 931-945.

Yenilmez, K. (2007). Attitudes of Turkish high school students toward mathematics. International Journal of Educational Reform, 16(4), 318-335.

Yenilmez, K., \& Ozabaci, N. S. (2003). With mathematics of student school students. Pamukkale University Faculty of Education Journal, 14 (14), 132-146 